\title{
Kolam Bioponik Bertenaga Surya untuk Ketahanan Pangan Masyarakat Kecamatan Singosari Kabupaten Malang
}

\author{
Nurhadi ${ }^{*}, 1$, Muhamad Rifa' ${ }^{2}{ }^{2}$, Chandra Wiharya ${ }^{3}$ \\ *,1, Jurusan Teknik Mesin, Politeknik Negeri Malang \\ ${ }^{2,3}$ Jurusan Teknik Elektro, Politeknik Negeri Malang \\ e-mail: *11 nurhadi@polinema.ac.id, ${ }^{2}$ muh.rifai@polinema.ac.id, ${ }^{3}$ chandra.wiharya@polinema.ac.id
}

\begin{abstract}
Abstrak
Pandemi COVID-19 berdampak pada melemahnya kemampuan ekonomi masyarakat RT $02 R W 13$ Desa Banjararum Kec. Singosari Kabupaten Malang. Dalam upaya menjamin ketahanan pangan, dikembangkan budidaya ikan lele bioponik (bio floc dan hidroponik), dibawah koordinasi UKM Citara. Dikarenakan terbatasnya kemampuan ekonomi, saat ini hanya mampu mengembangkan 3 unit kolam, sehingga hasilnya belum optimal. Untuk mengatasinya, dilakukan kegiatan pengabdian masyarakat berupa pemasangan kolam bioponik bertenaga surya. Metode pengabdian adalah metode difusi Ipteks, yaitu gabungan ilmu teknik mesin dan elektro untuk menghasilkan kolam bioponik bertenaga surya. Tahapan kegiatan meliputi penyiapan lokasi, mendesain, membuat dan memasang kolam bioponik bertenaga surya. Kolam dipasang di lahan kosong (lahan tak produktif) seluas kurang lebih 2000 meter $^{2}$ yang berada di pinggir sungai, sedangkan panel surya diletakkan diatas genteng yang terpapar sinar matahari langsung. Komponen controller, baterai, saklar, dl.l ditempatkan pada tempat yang aman, bebas dari panas dan hujan. Hasil kegiatan berupa 4 unit kolam bioponik bertenaga surya, masing-masing berdiameter $2 m$ dengan kapasitas 3.000 ekor ikan/kolam. Pompa air kolam digerakkan oleh panel surya berkapasitas 500 WP dan mampu menyala 12 jam/hari. Kolam bioponik bertenaga surya ini sangat penting untuk meningkatkan kapasitas produksi budidaya lele dan ketahanan pangan masyarakat di masa pandemi, sehingga potensial dikembangkan lagi di kemudian hari.
\end{abstract}

Kata kunci-kolam bioponik, tenaga surya, pemberdayaan masyarakat, Kec. Singosari

\section{PENDAHULUAN}

Merebaknya wabah Corona Virus Disease 2019 (COVID 19), berdampak pada berbagai sektor kehidupan. COVID-19 pertama kali ditemukan di kota Wuhan China pada akhir Desember 2019, menular dengan sangat cepat dan telah menyebar ke hampir semua negara termasuk Indonesia, hanya dalam waktu beberapa bulan, yaitu mulai pertengahan Maret 2020 [1]. Penyakit virus corona 2019 adalah nama baru yang diberikan oleh World Health Organization (WHO) bagi pasien dengan infeksi virus novel corona 2019 yang pertama kali dilaporkan dari kota Wuhan, Cina pada akhir 2019 [2]. Penyebaran penyakit ini telah memberikan dampak luas secara sosial dan ekonomi [3].

Wabah virus corona ini berdampak secara sosial dan ekonomi kepada hampir seluruh lapisan masyarakat, salah satunya adalah melemahnya kemampuan ekonomi masyarakat RT 02 RW 13 Desa Banjararum Kec. Singosari Kabupaten Malang. Hal ini mendorong masyarakat membuat terobosan baru untuk menjamin ketahanan pangan dan tetap mempunyai sumber penghasilan, yaitu dengan mengembangkan budidaya ikan lele bioponik (biofloc dan hidroponik) yang dimotori oleh Bapak Wahyu dari UKM Citara.

Budidaya ikan lele sistem bioponik merupakan penggabungan antara sistem biofloc dan hidroponik [4]. Budidaya ikan lele sistem bioflok dilakukan dengan menumbuhkan mikroorganisme yang berfungsi mengolah limbah budidaya itu sendiri menjadi gumpalan-gumpalan kecil (floc) yang justru bermanfaat sebagai makanan alami ikan. Teknologi bioflok atau lumpur aktif merupakan adopsi dari teknologi pengolahan biologis air limbah lumpur aktif dengan menggunakan aktivitas mikroorganisme untuk meningkatkan karbon dan nitrogen [5].

Budidaya ikan lele sistem bioflok tidak memerlukan lahan kolam yang luas, cukup kolam buatan menggunakan bahan terpal dengan rangka bambu atau besi, namun diperlukan pemasok sirkulasi oksigen dari dalam kolam, misalnya menggunakan aerator atau pompa air [6]. 
Hidroponik merupakan konsep budidaya tanaman yang memanfaatkan air tanpa membutuhkan tanah untuk media tanam. Sistem hidroponik mementingkan pemenuhan nutrisi tanaman, agar tanaman dapat hidup dan tumbuh [7]. Sedangkan hidroponik adalah inovasi dalam budidaya tanaman tanpa media tanah namun memanfaatkan nutrisi, air, serta bahan yang porus sebagai media tanam [8]. Hidroponik adalah cara bercocok tanam alternatif di perkotaan, mudah, terkendali, dan bisa dilakukan di media tanpa tanah, bahkan di dalam rumah [9].

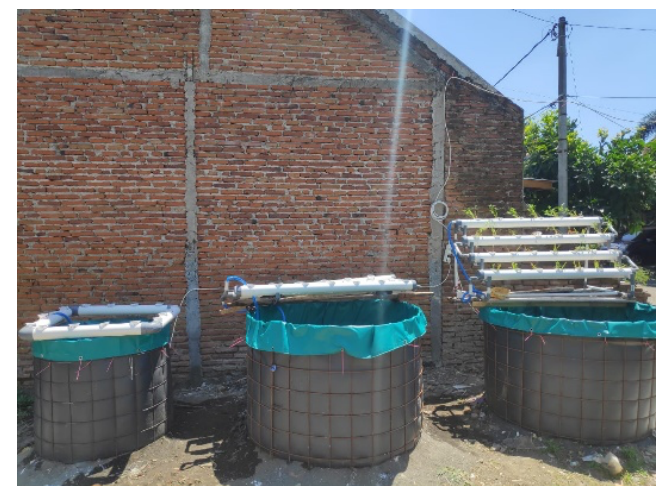

Gambar 1 Kolam ikan lele bioponik

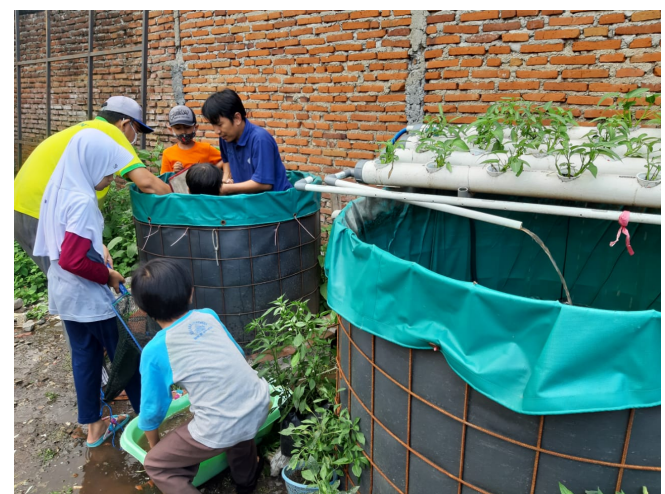

Gambar 2 Persiapan panen lele bioponik

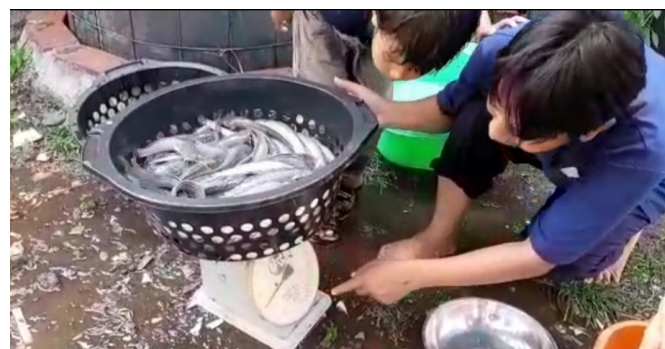

Gambar 3 Penimbangan hasil panen lele bioponik

Kemampuan ekonomi masyarakat yang terbatas karena terdampak pandemi COVID-19, menyebabkan masyarakat RT 02 RW 13 Desa Banjararum hanya mampu membangun 4 unit kolam, sehingga hasilnya belum optimal. Kolam bioponik tersebut juga membutuhkan pompa air yang bekerja 24 jam, namun UKM tidak memiliki sumber energi listrik alternatif sebagai penggerak pompa air sebagai penunjang proses budidaya ikan lele sedangkan biaya listrik PLN cukup tinggi sehingga membebani UKM [10]. Untuk mengatasi hal tersebut, maka kegiatan pengabdian masyarakat dilakukan melalui pemasangan kolam bioponik bertenaga surya ini.

\section{METODE}

\subsection{Program Kegiatan Pengabdian Masyarakat}

Kegiatan inti pada pengabdian masyarakat ini adalah memasang kolam bioponik bertenaga surya yang dilakukan dalam beberapa tahapan kegiatan, yaitu menyiapkan lokasi, mendesain, membuat dan memasang kolam bioponik bertenaga surya.

Kolam dipasang di lahan kosong (lahan tak produktif) seluas kurang lebih 2.000 meter $^{2}$ yang berada di pinggir sungai, sedangkan panel surya diletakkan diatas genteng yang terpapar sinar matahari langsung. Komponen controller, baterai, saklar, dll. ditempatkan pada tempat yang aman, bebas dari panas dan hujan.

\subsection{Analisis Kebutuhan Program}

Jumlah kolam ikan lele bioponik yang dimiliki UKM Citara sebelumnya sebanyak 4 unit kolam dengan diameter masing-masing sebesar 1,5 $\mathrm{m}^{2}$. Masing-masing kolam bisa diisi benih lele dengan ukuran panjang 5-7 cm sebanyak 3.000 ekor (maksimum), sehingga kapasitas kolam maksimum 12.000 ekor. Waktu yang dibutuhkan untuk sekali panen rata-rata 3 bulan dengan Survival Rate (SR) $80 \%$, artinya mulai dari pembenihan hingga panen, angka hidup ikan adalah $80 \%$, sehingga saat panen diperoleh hasil rata-rata $80 \%$ x 12.000 ekor $=9.600$ ekor. Ukuran ikan saat panen (size) yaitu $1 \mathrm{~kg}$ size 12 , artinya pada saat panen untuk $1 \mathrm{~kg}$ berat ikan berisi 12 ekor, sehingga jumlah berat ikan yang diperoleh saat panen yaitu $9.600 / 12=800 \mathrm{~kg}$. Harga rata-rata ikan lele per kg adalah Rp. 20.000, sehingga saat panen diperoleh omzet $800 \mathrm{~kg} \times \mathrm{Rp} .20 .000=$ Rp 16.000.000 per 3 bulan.

Dengan penambahan 4 unit kolam dengan diameter yang lebih besar ( 2 meter) maka diharapkan mampu meningkatkan kapasitas produksi budidaya ikan lele sebanyak 2 kali lipat, apalagi kalau pompa kolam lele tersebut tidak menggunakan listrik PLN, tetapi menggunakan tenaga surya, maka keuntungan yang bisa didapatkan akan semakin meningkat.

\subsection{Pendekatan yang Digunakan Dalam}




\section{Menjalankan Program}

Model atau pendekatan yang digunakan dalam menjalankan kegiatan pengabdian masyarakat ini adalah difusi Ipteks, yaitu gabungan ilmu teknik mesin dan elektro untuk menghasilkan produk kolam bioponik bertenaga surya.

Desain dan pembuatan kolam bioponik menggunakan pendekatan ilmu Teknik Mesin, sedangkan desain dan pemasangan panel surya ,menggunakan pendekatan ilmu Teknik Elektro.

Adapun tahapan pelaksanaan program meliputi koordinasi, implementasi dan evaluasi. Koordinasi dilakukan antara ketua tim pengabdian masyarakat, anggota dosen, anggota mahasiswa dan mitra, baik secara luar jaringan (luring) maupun dalam jaringan (daring) via zoom.

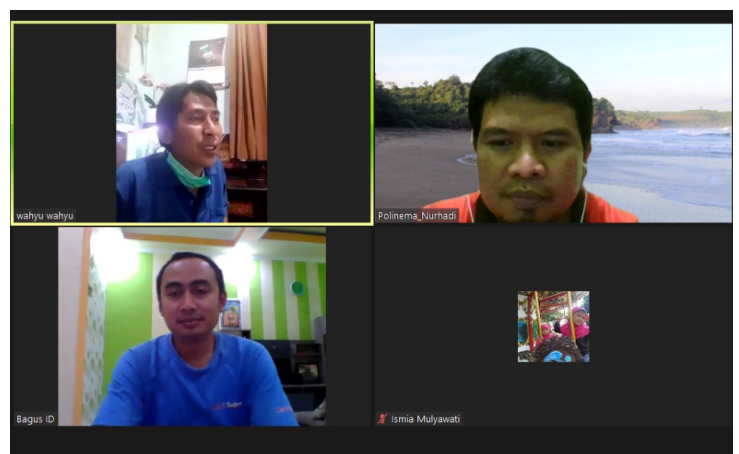

Gambar 4 Koordinasi daring dengan tim UKM

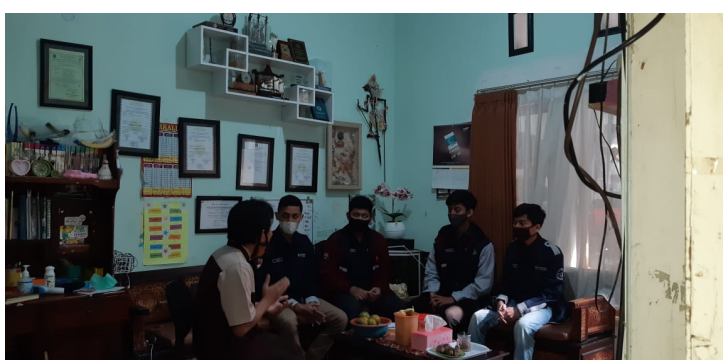

Gambar 5 Koordinasi luring dengan tim mahasiswa

Pemasangan kolam bioponik bertenaga surya ini melibatkan tim pengabdi dari unsur dosen, mahasiswa dan mitra pengabdian.

Evaluasi kegiatan dilakukan dengan menguji apakah kolam bioponik bertenaga surya yang direncanakan bisa bekerja dengan baik atau tidak.

\subsection{Peserta yang Terlibat}

Peserta yang terlibat pada kegiatan pengabdian masyarakat ini terdiri dari 3 unsur, yaitu:

1. Dosen sebagai pelaksana kegiatan terdiri dari 3 orang, yaitu 1 orang Dosen Teknik Mesin dan 2 orang Dosen Teknik Elektro.

2. Mahasiswa yang terlibat membantu kegiatan pengabdian masyarakat ini sebanyak 4 orang, yaitu mahasiswa kelas 3 Program Studi D-IV Teknik Otomotif Elektronik.

3. Masyarakat sebagai mitra kegiatan pengabdian masyarakat ini adalah UKM Citara yang memiliki anggota sebanyak \pm 20 orang.

\subsection{Penyelesaian Masalah di lingkungan Kegiatan Pengabdian}

Penyelesaian masalah di lingkungan kegiatan pengabdian yaitu UKM Citara RT 02 RW 13 Desa Banjararum Kec. Singosari Kabupaten Malang adalah dengan memberikan bantuan berupa 4 unit kolam bioponik bertenaga surya.

Tahapan kegiatan meliputi: menyiapkan lokasi, mendesain, membuat, memasang dan menguji coba kolam bioponik bertenaga surya.

Pemasangan kolam pada lahan kosong yang tidak produktif bertujuan untuk pemberdayaan lahan tersebut, sedangkan pemasangan panel surya diatas genteng yang terpapar sinar matahari langsung bertujuan agar mendapatkan sinar matahari yang maksimal sehingga dapat menghasilkan listrik yang optimal. Komponen controller, baterai, saklar, dll. ditempatkan pada tempat yang aman, bebas dari panas dan hujan, yaitu di salah satu rumah warga, agar lebih awet dan tidak hilang, karena harganya yang cukup mahal.

\subsection{Hasil Yang Diinginkan dalam Menjalankan Program}

Beberapa hasil yang diinginkan dalam menjalankan program pengabdian masyarakat ini yaitu:

1) Terpasangnya 4 unit kolam bioponik bertenaga surya, masing-masing berdiameter 2 meter dengan kapasitas 4.000 ekor ikan/kolam. Pompa air kolam digerakkan oleh panel surya berkapasitas 500 WP. dengan penambahan 4 unit kolam ini diharapkan bisa meningkatkan kapasitas produksi budidaya ikan lele.

2) Menggunakan lahan kosong di pinggir sungai, dari tidak produktif menjadi lahan produktif.

3) Pemberdayaan masyarakat dan mewujudkan upaya peningkatan ketahanan pangan di masa pandemi.

\section{HASIL DAN PEMBAHASAN}

\subsection{Tahapan kegiatan}

Hasil pelaksanaan kegiatan pengabdian masyarakat terdiri dari beberapa sub kegiatan, yaitu:

1) Penyiapan lahan untuk kolam bioponik

Lahan yang digunakan untuk pengembangan budidaya ikan lele dalam kolam bioflok adalah 
lahan kosong di pinggir sungai, konturnya miring dan tidak produktif seluas kurang lebih $2.000 \mathrm{~m}^{2}$.

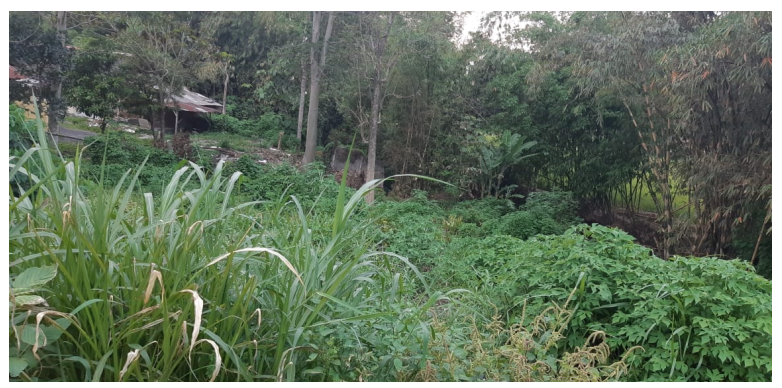

Gambar 6 Lahan kosong dengan kontur miring

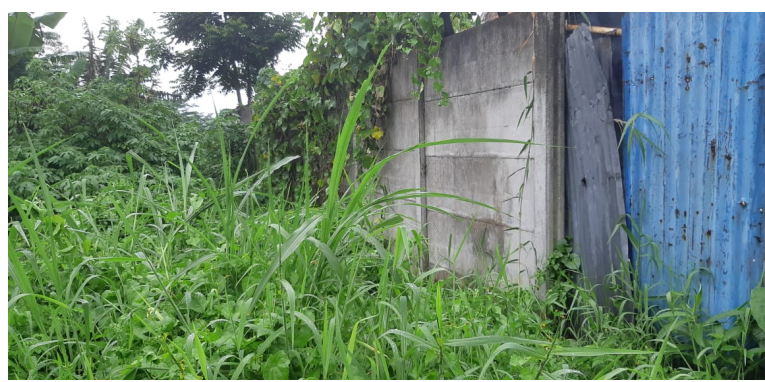

Gambar 7 Lahan kosong tidak produktif

Penyiapan lahan dilakukan dengan membersihkan rumput-rumput liar di area lahan kosong tersebut, meratakan tanah, dan lain-lain dalam kegiatan kerjabakti bersama warga sekitar.

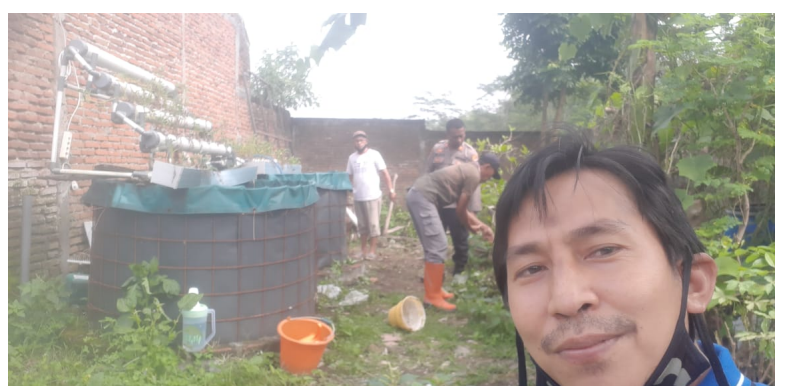

Gambar 8 Kerjabakti penyiapan lahan

2) Pelatihan pembuatan kolam bioponik

Pelatihan ini dilakukan sebelum pemasangan kolam bioponik agar semua tim yang bekerja memiliki pemahaman dan persepsi yang sama, sehingga diperoleh hasil yang optimal. Untuk menginformasikan kegiatan pelatihan diberikan pengumuman dalam bentuk flyer.

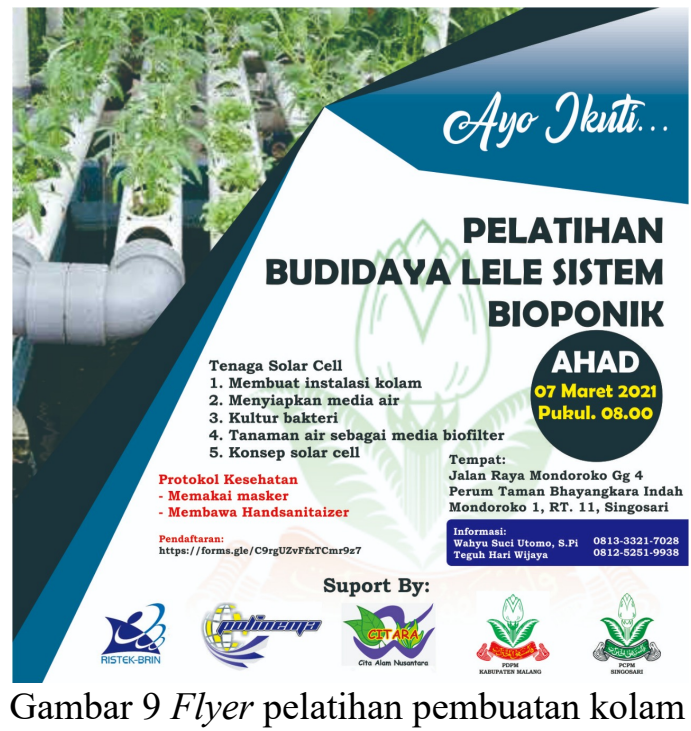

Pelatihan dilaksanakan pada hari Minggu, 7 Maret 2021 mulai jam 09.00 WIB yang diikuti oleh unsur dosen, mahasiswa dan anggota UKM. Pelatihan dilanjutkan dengan praktek langsung membuat kolam bioponik.

3) Pemasangan kolam bioponik

Pemasangan kolam bioponik merupakan kelanjutan dari kegiatan pelatihan sebelumnya.

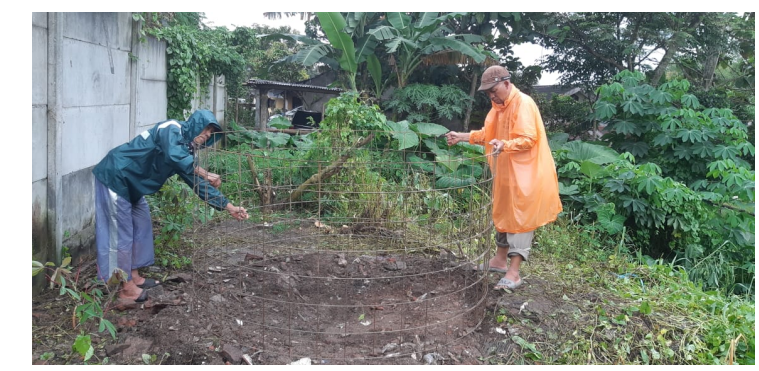

Gambar 10 Memulai pemasangan kolam bioponik

Pada Gambar 10 tampak bahwa dasar kolam dibuat cekung ke tengah karena posisi saluran pembuangan air kolam berada di dibagian tengah, sehingga air bisa mengalir dengan baik saat dilakukan pengurasan/pembersihan kolam.

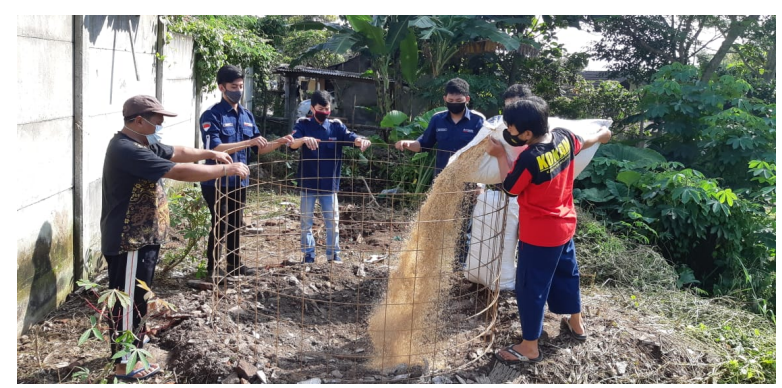

Gambar 11 Meratakan dasar kolam bioponik dengan sekam 
Pemberian sekam sebagaimana Gambar 11 bertujuan untuk meratakan dasar kolam dan sebagai penghangat kolam secara alami. Sekam memiliki sifat yang panas, sehingga dasar kolam tidak mudah dingin karena secara secara alami dihangatkan oleh sekam.

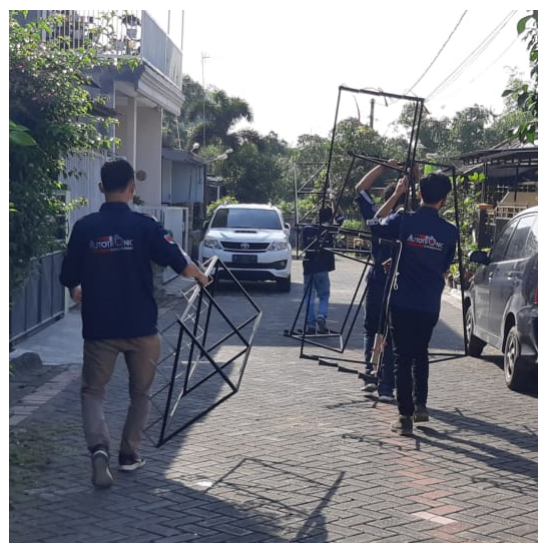

Gambar 12 Penyiapan rangka hidroponik

Rangka hidroponik dipasang pada bagian atas kolam sebagai penyangga media tanam dan saluran air tanaman hidroponik. Rangka dibuat dari besi profil kotak $3 \times 3 \mathrm{~cm}$ berbentuk segitiga siku-siku dengan ukuran tinggi dan lebar disesuaikan dengan diameter kolam. Pada rangka terdapat 3 tingkat saluran air media tanam tanaman hidroponik sebagaimana Gambar 13.

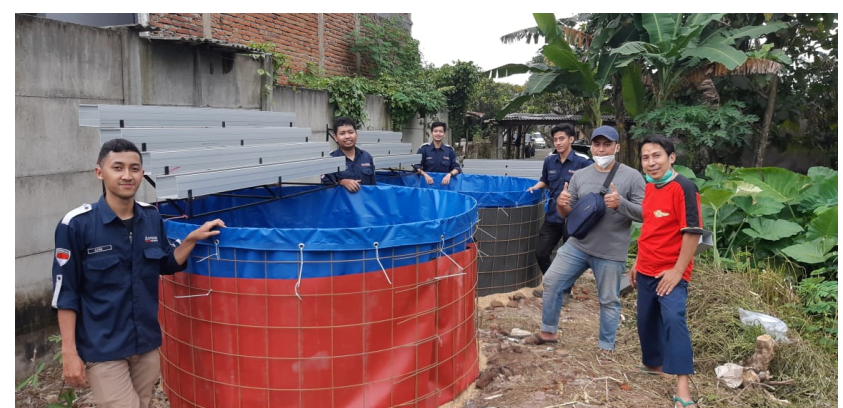

Gambar 13 Kolam bioponik yang sudah jadi

Kolam bioponik sebagaimana Gambar 13 merupakan gabungan dari kolam bioflok dan hidroponik. Pada bagian bawah terdapat kolam terpal bioflok dan diatasnya diberikan media tanam tanaman hidroponik. Di dalam kolam dipasang pompa yang memompa air kolam ke atas tanaman hidroponik. Selain agar terjadi sirkulasi air secara terus menerus sehingga ikan tidak kekurangan oksigen, juga untuk menyalurkan floc (gumpalan) feses ikan ke tananam hidroponik sebagai nutrisi tanaman tersebut.

4) Penyiapan desain instalasi panel surya
Desain instalasi panel surya untuk kolam bioponik terdiri dari komponen 5 komponen utama, yaitu: panel surya, controller hybrid, baterai, pompa dan lampu penerangan.

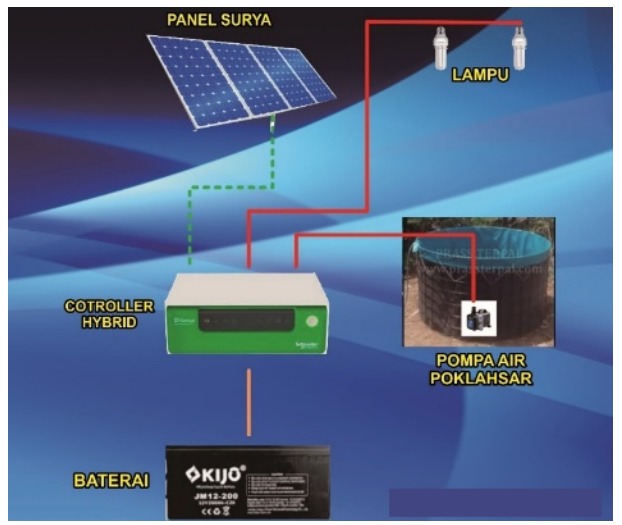

Gambar 14 Desain instalasi panel surya

Spesifikasi teknis tiap komponen pada Gambar 14 yaitu 5 unit panel surya masing-masing $100 \mathrm{WP}$ (500 WP), 1 unit controller hybrid $850 \mathrm{VA}, 1$ unit baterai VRLA $200 \mathrm{AH}, 4$ unit pompa air 25 watt (untuk 4 kolam) dan 2 unit lampu LED masingmasing 14 watt.

Panel surya berfungsi sebagai penangkap cahaya matahari dan mengubahnya menjadi listrik DC. Terdapat 5 unit panel surya masing-masing 100 watt peak (WP) tipe monokristalin. Baterai berfungsi sebagai penyimpan tegangan listrik dari panel surya dan sebagai sumber energi listrik untuk menyalakan beban saat tidak ada cahaya matahari. Baterai yang digunakan adalah tipe Valve Regulated Lead Acid (VRLA), yaitu baterai kering yang terdapat katup yang berfungsi menjaga cairan atau elektrolit tidak mudah menguap meski terjadi getaran atau goncangan. Kapasitas baterai yang dipilih adalah 12 volt 200 $\mathrm{AH}$, sedikit diatas kapasitas minimum yang dihasilkan dari desain/perhitungan. Controller berfungsi sebagai pengontrol tegangan dan arus listrik yang dihasilkan panel surya untuk digunakan menyalakan beban maupun mengisi baterai. Dinamakan controller hybrid karena didalamnya sudah terdapat inverter yang berfungsi mengubah tegangan DC ke AC. Controller yang digunakan adalah merek Homaya dengan kapasitas maksimum $850 \mathrm{AH}$. Pompa air merupakan beban utama sistem panel surya dan berfungsi sebagai penghasil oksigen pada kolam hidroponik agar ikan lele tidak kekurangan oksigen dan tidak mudah mati. Pompa air yang dipilih adalah pompa kolam dengan daya 25 watt 
yang mampu menaikkan air dari kolam ke instalasi hidroponik. Terdapat 4 kolam yang digerakkan oleh pompa air, sehingga total daya pompa sebesar 100 watt. Lampu berfungsi sebagai penerangan kolam di malam hari dan sebagai beban tambahan. Lampu yang digunakan sebanyak 2 unit lampu LED dengan daya masingmasing 14 watt AC. Spesifikasi tersebut dipilih karena sudah mampu menerangi kolam dan area sekitarnya.

Selain komponen utama diatas, terdapat beberapa komponen tambahan, yaitu $\mathrm{MCB}$, volmeter dan amperemeter. MCB berfungsi sebagai pengendali (penyambung dan pemutus) arus listrik, baik DC maupun AC. Voltmeter dan ampermeter berfungsi mengukur tegangan dan arus listrik keluaran sistem panel surya.

5) Pemasangan instalasi panel surya

Panel surya dipasang ditempat yang paling banyak mendapatkan sinar matahari sepanjang hari, yaitu diatas genteng, sedangkan baterai dan controller dipasang di tempat yang terlindungi dari panas dan hujan agar awet, yaitu didalam rumah.

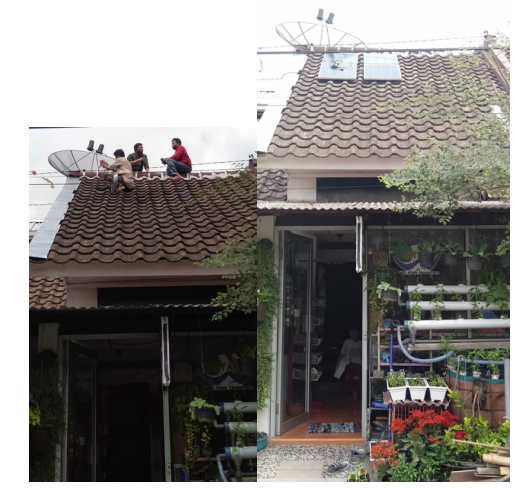

Gambar 15 Pemasangan panel surya

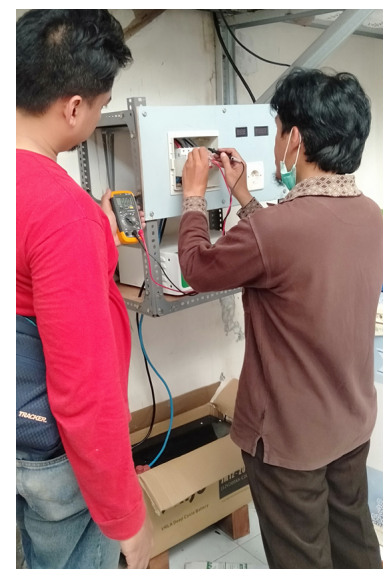

Gambar 16 Pemasangan controller hybrid dan baterai
Gambar 16 menunjukkan proses pemasangan controller hybrid dan baterai, dimana controller dipasang pada rak besi setinggi $\pm 1,5$ meter dari lantai. Hal ini dimaksudkan agar memudahkan proses pengoperasian. Baterai diletakkan dibawah controller agar kebutuhan kabel dari baterai ke controller cukup pendek. Kardus pembungkus baterai sengaja tidak dibuang agar baterai terlindungi dari kotoran. Di bawah baterai diberi balok kayu agar baterai tidak menempel langsung ke lantai yang kemungkinan lembab dan bisa merusak baterai, dan agar memudahkan pemindahan jika diperlukan, karena baterai sangat berat.

6) Uji coba instalasi panel surya

Uji coba dilakukan dengan menghubungan kabel output panel surya pada panel controller ke beban listrik (pompa air kolam bioponik dan lampu) dan menyalakan saklar MCB.

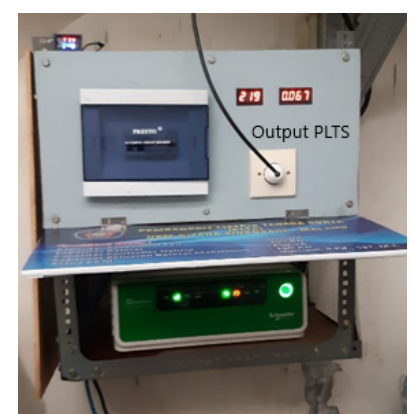

Gambar 17 Uji coba instalasi panel surya

Saat saklar-saklar MCB di ON kan, maka indikator pada controller menyala hijau yang menunjukkan ada tegangan listrik dari panel surya yang diterima controller. Selain itu voltmeter dan amperemeter juga menunjukkan tegangan arus yang sedang bekerja. Hasil uji coba menunjukkan bahwa pompa air dan lampu penerangan dapat menyala/berfungsi dengan baik. Dalam kondisi sinar matahari cerah, instalasi panel surya mampu digunakan untuk menyalakan 4 unit pompa air kolam bioponik selama 24 jam dan lampu penerangan selama $12 \mathrm{jam}$.

\subsection{Peningkatan Kapasitas Produksi}

Peningkatan kapasitas produksi budidaya ikan lele UKM Citara dihitung berdasarkan kondisi sebelum dan sesudah kegiatan pengabdian masyarakat.

Sebelum kegiatan pengabdian masyarakat, jumlah kolam ikan lele biofloc yang dimiliki UKM Citara sebanyak 4 unit kolam masing-masing 
berdiameter 1,5 $\mathrm{m}$. Setiap kolam bisa diisi benih lele ukuran panjang 5-7 cm sebanyak 1.500 ekor (maksimum), sehingga kapasitas kolam maksimum 6.000 ekor. Waktu yang dibutuhkan untuk sekali panen rata-rata 3 bulan dengan Survival Rate (SR): $80 \%$, artinya mulai dari pembenihan hingga panen, angka hidup ikan adalah $80 \%$, sehingga saat panen diperoleh hasil rata-rata $80 \% \times 6.000$ ekor $=4.800$ ekor. Ukuran ikan saat panen (size) yaitu $1 \mathrm{~kg}$ size 12 , artinya pada saat panen untuk $1 \mathrm{~kg}$ berat ikan berisi 12 ekor, sehingga jumlah berat ikan yang diperoleh saat panen yaitu $4.800 / 12=400 \mathrm{~kg}$. Harga terendah ikan lele (harga pengepul) per kg adalah $\mathrm{Rp}$. 16.000 , sehingga saat panen diperoleh omzet $400 \mathrm{~kg}$ $\mathrm{x}$ Rp. $16.000=\mathrm{Rp} 6.400 .000$ per 3 bulan. Perhitungan biaya produksi dengan biaya pakan ikan lele menggunakan istilah Food Convertion Ratio (FCR), dimana FCR merupakan perbandingan antara total pakan dengan total produksi. Harga pakan per kg adalah Rp. 10.500,-, sehingga biaya pakan per 1 $\mathrm{kg}$ ikan adalah $1,2 \mathrm{~kg}$ pakan $\mathrm{x}$ Rp. $10.500=\mathrm{Rp}$. 12.600,-. Harga ikan lele per kg saat panen adalah Rp $16.000,-$, sehingga keuntungan produksi per kg ikan diperoleh Rp 16.000 - Rp. 12.600 = Rp. 3.400,-. Untuk sekali panen per 3 bulan diperoleh hasil ikan $400 \mathrm{~kg}$, sehingga keuntungan produksi per panen adalah $400 \mathrm{~kg}$ x Rp. $3.400=\mathrm{Rp} 1.360 .000,-$

Setelah kegiatan pengabdian masyarakat, jumlah kolam ikan lele biofloc yang dimiliki UKM Citara sebanyak 10 unit kolam, dengan rincian 4 kolam berdiameter masing-masing $1,5 \mathrm{~m}$ dan 6 kolam berdiameter masing-masing $2 \mathrm{~m}$. Kapasitas ikan lele sbb:

1. Kolam berdiameter 1,5 m: 4 x $1500=6.000$ ekor

2. Kolam berdiameter 2 m: 6 × $3000=18.000$ ekor

Total: 24.000 ekor

Dengan perhitungan yang sama, diperoleh hasil untuk sekali panen (3 bulan) sbb:

- SR: $80 \%$ x 24.000 ekor $=19.200$ ekor.

- jumlah berat ikan: $19.200 / 12=1600 \mathrm{~kg}$.

- keuntungan produksi $1600 \mathrm{~kg}$ x Rp. $3.400=\mathrm{Rp}$ 5.440.000,-

Dari uraian diatas dapat digarisbawahi bahwa kapasitas produksi semula (sebelum kegiatan pengabdian masyarakat) dengan 4 kolam sebanyak $400 \mathrm{~kg}$, sedangkan setelah kegiatan pengabdian masyarakat dengan 10 kolam didapatkan hasil panen sebanyak $1.600 \mathrm{~kg}$, sehingga terjadi peningkatan sebesar 4 kali.

\subsection{Kebutuhan Pakan}

Dengan meningkatnya kapasitas produksi dari semula 4 kolam (6.000 ekor) menjadi 10 kolam (24.000 ekor), kebutuhan pakan juga otomatis meningkat tajam. Hal ini justru menjadi peluang usaha baru yaitu menyediakan dan membuat pakan sendiri, selain pakan buatan pabrik berupa pellet. Pakan buatan dibuat dari sisa-sisa kepala ikan dan bahan campuran lain seperti bekatul yang diperoleh dari pasar tradisional dengan harga murah. Peningkatan jumlah dan biaya pakan tidak menjadi masalah dan tidak mempengaruhi keuntungan produksi, karena perhitungan biaya produksi sebelumnya sudah memperhitungkan faktor pakan, yang disebut dengan istilah Food Convertion Ratio (FCR), dimana FCR merupakan perbandingan antara total pakan dengan total produksi.

\subsection{Pengukuran Penggunaan Energi Listrik Panel Surya}

Instalasi PLTS terdiri dari 5 unit panel surya masing-masing $100 \mathrm{WP}$ (500 WP), 1 unit controller hybrid 850 VA, 1 unit baterai VRLA $200 \mathrm{AH}, 2$ unit lampu masing-masing 14 watt, saklar MCB, voltmeter, dan amperemeter.

Kemampuan pembangkitan energi listrik dari panel surya rata-rata perhari dalam kondisi cahaya matahari cerah adalah 960 watt untuk 2 jam pemakaian, atau 160 watt untuk 12 jam pemakaian, atau 80 watt untuk 24 jam pemakaian. PLTS dapat menyalakan pompa air kolam lele selama 24 jam/hari dan menyalakan 2 lampu penerangan jalan selama 12 jam/hari.

Sebelum kegiatan pengabdian masyarakat, 4 unit kolam lele bioponik menggunakan pompa air masing-masing 25 watt menggunakan listrik PLN. Biaya listrik tiap kolam rata-rata Rp. 100.000 per bulan, sehingga total biaya listrik 4 kolam untuk sekali panen ( 3 bulan) adalah $4 \times 3 \times 100.000=R$. 1.200.000,-

Setelah kegiatan pengabdian masyarakat, dengan adanya PLTS, maka dilakukan penggantian spesifikasi pompa air. Semula tiap kolam menggunakan 1 unit pompa masing-masing 25 watt, diganti dengan pompa blower 60 watt yang mampu digunakan untuk 10 kolam. Dipilih pompa jenis blower dengan daya yang tidak terlalu besar, karena memang kebutuhan kolam lele yang utama adalah oksigen yang dihasilkan oleh aerator pompa blower, dan pompa dengan daya 60 watt tersebut mampu digerakkan oleh PLTS dengan kapasitas daya output 80 watt $/ 24 \mathrm{jam}$.

Terjadi penurunan biaya listrik yang cukup signifikan dimana semula kebutuhan biaya listrik sebesar Rp. 1.200.000 untuk 4 kolam, menjadi Rp. 0 ,- untuk 10 kolam.

\section{KESIMPULAN}


Berdasar pembahasan terhadap hasil kegiatan pengabdian masyarakat ini, dapat disimpulkan bahwa kegiatan pengabdian masyarakat ini:

1. Menghasilkan luaran berupa 4 unit kolam bioponik, masing-masing berdiameter 2 meter dengan kapasitas 3.000 ekor ikan/kolam, yang dihibahkan kepada UKM Citara. Kelebihan diameter kolam lebih besar dari yang sudah ada, namun membutuhkan bibit, pakan yang lebih banyak.

2. Menghasilkan 1 unit instalasi panel surya penggerak pompa air kolam bioponik berkapasitas 500 WP. Kelebihannya instalasi panel surya mampu digunakan untuk menyalakan 4 unit pompa air masing-masing 25 watt selama 24 $\mathrm{jam} / \mathrm{hari}$ dan 2 unit lampu penerangan LED masing-masing 14 watt selama $12 \mathrm{jam} / \mathrm{hari}$. Empat unit pompa tersebut mampu digerakkan oleh PLTS dalam arti diganti dengan 1 unit pompa blower 60 watt untuk 10 kolam. Kelemahannya bahwa waktu cadangan (days of autonomy) yang diberikan hanya 1-2 hari saja. Jika kondisi cuaca mendung lebih dari 2 hari, maka kemampuan tersebut bisa tidak tercapai.

\section{SARAN}

Kolam bioponik bertenaga surya ini sangat penting untuk meningkatkan kapasitas produksi budidaya lele dan ketahanan pangan masyarakat di masa pandemi, sehingga potensial dikembangkan lagi di kemudian hari, yaitu dengan cara menambah kapasitas baterai, kapasitas panel surya dan jumlah kolam.

\section{UCAPAN TERIMA KASIH}

Penulis mengucapkan terima kasih kepada DRPM Ristek/BRIN yang telah memberi dukungan dana dan kepada UPT P2M Polinema yang telah memberi dukungan moral serta kepada UKM Citara selaku Mitra, sehingga kegiatan pengabdian masyarakat ini dapat terlaksana dengan baik.

\section{DAFTAR PUSTAKA}

[1] Anonim, 2020, Virus Corona, dari https://www.alodokter.com/virus-corona, diakses tgl. 6 Juli 2020.

[2] Handayani, D., Hadi, D. R., Isbaniah, F., Burhan, E., \& Agustin, H., 2020, Penyakit Virus
Corona 2019, Jurnal Respirologi Indonesia, 40(2), 119-129.

[3] Susilo, A., Rumende, C. M., Pitoyo, C. W., Santoso, W. D., Yulianti, M., Herikurniawan, H., Nelwan, E. J., 2020, Coronavirus Disease 2019: Tinjauan Literatur Terkini, Jurnal Penyakit Dalam Indonesia, 7(1), 45-67.

[4] Utomo, Suci, W., 2020, Company Profile Poklahsar Citara, Banjararum, Singosari, Malang.

[5] Faridah, F., Diana, S., \& Yuniati, Y., 2019, Budidaya Ikan Lele Dengan Metode Bioflok Pada Peternak Ikan Lele Konvesional, CARADDE: Jurnal Pengabdian Kepada Masyarakat, 1(2), 224-227.

[6] Manggala P. Putra, Yudha, 2015, Budidaya Lele Bersistem Bioflok Hasilnya 10 Kali Lipat, https://republika.co.id/berita/nasional/daerah/15/ 11/23/ny9rm4284-budidaya-lele-bersistembioflok-hasilnya-10-kali-lipat, diakses tgl. 10 Oktober 2020.

[7] Murniaseh, E., 2020, Teknik Cara Menanam Hidroponik \& Jenis Tanaman yang Cocok, https://tirto.id/teknik-cara-menanam-hidroponikjenis-tanaman-yang-cocok-fXTf, diakses tanggal 25 Oktober 2020.

[8] Kamalia, S., Dewanti, P., \& Soedradjad, R., 2017, Teknologi Hidroponik Sistem Sumbu Pada Produksi Selada Lollo Rossa (Lactuca sativa L.) Dengan Penambahan $\mathrm{CaCl} 2$ Sebagai Nutrisi Hidroponik, Jurnal Agroteknologi, 11(01), 96-104.

[9] Rakhman, A., 2015, Pertumbuhan tanaman sawi menggunakan sistem hidroponik dan akuaponik, FAKULTAS PERTANIAN.

[10] Anonim, 2020, Daftar Tarif Listrik Terbaru 2020 Kementerian ESDM [Oktober Desember], https://ifepal.co.id/media/daftartarif-listrik-terbaru/, diakses tanggal 10 Oktober 2020. 